\title{
Effect of seed storage temperature on fine root development and mycorrhizal colonization of young Populus nigra seedlings
}

\author{
Joanna Mucha ${ }^{1}$ - Agata Klaudia Szymańska ${ }^{1,2} \cdot$ Marcin Zadworny $^{1}$. \\ Tadeusz Tylkowski ${ }^{1} \cdot$ Marcin Michalak $^{1} \cdot$ Jan Suszka $^{1}$
}

Received: 25 September 2014 / Accepted: 3 March 2015 / Published online: 27 March 2015

(C) The Author(s) 2015. This article is published with open access at Springerlink.com

\begin{abstract}
- Key message Seed storage temperature influences root anatomy of the endangered Populus nigra, and consequently may alter nutrient absorption. A lower temperature during seed storage $\left(-20\right.$ and $\left.-196^{\circ} \mathrm{C}\right)$ may preserve the potential for a suitable root system development after germination.

- Context Seed storage conditions can be an important determinant of later seedling growth of Populus nigra L., an endangered tree species.

- Aims We tested whether long-term seed storage temperature, $-10,-20$ or $-196{ }^{\circ} \mathrm{C}$, affects the pattern of seedling root traits responsible for resource acquisition as compared to seedlings of fresh seeds.

- Methods We analysed the morphology, anatomy, degree of mycorrhizal colonization, and biochemical composition of

\footnotetext{
Handling Editor: Ana Rincon

Contribution of co-authors Joanna Mucha: conducting the experiment, analyzing the data, writing the manuscript. Agata Klaudia Szymańska: conducting the experiment, analyzing the data. Marcin Zadworny: conducting the experiment, writing the manuscript. Tadeusz Tylkowski: designing and conducting the experiment, writing the manuscript. Marcin Michalak: designing and conducting the experiment, writing the manuscript. Jan Suszka: coordinating the research project, designing and supervising the experiment, writing the manuscript.
}

Electronic supplementary material The online version of this article (doi:10.1007/s13595-015-0470-0) contains supplementary material, which is available to authorized users.

Joanna Mucha

jmucha@man.poznan.pl

1 Institute of Dendrology, Polish Academy of Sciences, Parkowa 5, 62-035 Kórnik, Poland

2 Faculty of Forestry, Poznań University of Life Sciences, Poznań, Poland roots developed from seed stored for 24 months at five different temperatures (from 3 to $-196{ }^{\circ} \mathrm{C}$ ) commonly used to preserve genetic resources.

- Results Except for root anatomy, we found no relationship between seed storage temperature and the root traits of seedlings. Among the various storage conditions, the proportion of roots with primary development in the first four orders was similar in seedlings developed from fresh seeds of from seeds stored at -196 or $-20{ }^{\circ} \mathrm{C}$. Nitrogen content in the roots was positively correlated with the proportion of (i) roots with primary development and (ii) the cortex width in the root diameter.

- Conclusions Higher temperatures during seed storage reduced the proportion of roots with absorptive function (with primary development). Therefore, for preservation of $P$. nigra seeds we recommend lower temperatures such as -20 and $-196^{\circ} \mathrm{C}$.

Keywords Anatomy - Arbuscularmycorrhiza - Black poplar · Primary development · Root absorptive function ·

Seed storage temperature

\section{Introduction}

Populus nigra L. is a species that occurs within a riparian ecosystem and is widely distributed throughout the northern hemisphere, with a geographical range from Central and South Europe to Central Asia and North Africa (Storme et al. 2004). In Europe, approximately $99 \%$ of the riparian forests are projected to disappear by human use and the regulation of river systems (Lefèvre et al. 1998; Hughes and Rood 2003). As a consequence, $P$. nigra has become an endangered species (Braatne et al. 1996; Storme et al. 2004). Thus, P. nigra has been the object of conservation and restoration programs 
(Lefèvre et al. 1998; Villar and Forestier 2006), whose success has required increasing knowledge of the ecology and genetics of P. nigra (Hughes and Rood 2003).

The life cycle of riparian black poplar is adapted to hydrogeomorphological conditions (Corenblit et al. 2014). These morphological, physiological, and biochemical adaptations ensure growth in a disturbed, unstable, and fluctuating environment (Lytle 2001). In particular, root systems, especially their rapid development, diminish seedling mortality caused by drought in the first summer after seeds have germinated, and the uprooting of plants during winter floods (Karrenberg et al. 2003). The specific environmental conditions in natural habitats have favored the evolution of preferential root development of $P$. nigra during the first few years of seedling growth to ensure anchorage and resource acquisition via fine roots (with diameter $<2 \mathrm{~mm}$ ) (Braatne et al. 1996; Hodge et al. 2009), what is essential in biomass production (FernándezMartínez et al. 2014). The function of the root system of P. nigra is also affected by a symbiotic interaction with specific endo- and ectomycorrhizal fungi (Gryta et al. 2006; Harner et al. 2010). Arbuscular mycorrhizal (AM) fungi contribute to the availability of plant nutrients, including nitrogen (Leigh et al. 2009), which is essential to the establishment and growth of young P. nigra seedlings (Rooney et al. 2011).

Seed storage is the most effective way of preserving the genetic diversity of a plant species (Linington and Pritchard 2001). P. nigra produces very abundant, non-dormant and short-lived seeds (Seiwa et al. 2008). This requires the development of seed storage methods that can retain the ability of seeds to germinate after many years. Various seed storage temperatures have been reported for P. nigra, which have resulted in the ability to store the seeds for different lengths of time and still retain sufficient levels of seed viability (Stanton and Villar 1996; Tylkowski 2010; Michalak et al. 2014; Suszka et al. 2014). Thus far in the literature, optimal seed storage conditions have been assessed on the basis of seed germination (Popova et al. 2012; Malik et al. 2013; Suszka et al. 2014) or seedling emergence (Michalak et al. 2013; Popova et al. 2013). These parameters do measure the impact of storage temperature on seed viability and initial emergence. However, these assessments may not be sufficient to fully understand the impact of seed storage temperature on the ability of seedlings to successfully establish themselves and grow vigorously in the field, as seedlings need to adapt to the prevailing environmental conditions and to exhibit good development of both shoots and roots.

While there are some data about shoot development and growth after seed storage (Martinez-Montero et al. 2002; Caswell and Kartha 2009), there is insufficient information on root system development, since different seed storage conditions may affect the subsequent quality of seedlings (viability and vigor). Stored seeds are subject to various storage disorders that may have a negative impact on seedlings, compared to seedlings derived from seeds that were not stored. Stadelmann et al. (1998) reported differences in the morphological and physiological characteristics of seedlings derived from seeds of two grass species that were stored in liquid nitrogen. A low concentration of nitrogen was observed in the seedlings of Festuca rubra L. due to the weak development of the root system (Stadelmann et al. 1998). Importantly, a well-developed root system is a prerequisite for adequate colonization by mycorrhizal fungi that enhance nutrient acquisition. Thus, attention should be paid to the interspecific variation in the dynamics of mycorrhizal colonization of seedlings derived from stored versus fresh seed, as Stadelmann et al. (1998) indicated a high level of variability and mycorrhizal colonization of seedlings of F. rubra and Lolium perenne $\mathrm{L}$. that were grown under the same environmental conditions but whose seeds had or had not been subjected to cryopreservation. These results indicate that cryopreservation may not be appropriate for every species, and even the possibility of significant variation in the effect of cryopreservation and other storage conditions on seeds between individual populations of the same species.

Given the importance of well-developed root systems in supplying adequate nutrients for growth and for preventing the dislodging of $P$. nigra by adverse environmental conditions such as high wind or flooding (Braatne et al. 1996), it is critical that the formed root system after storage of seeds is extremely similar to that derived from seed which has not been stored. Currently, there is not sufficient information pertaining to how storage conditions induce biochemical changes in seeds that can influence subsequent seedling development (Sershen and Pammeneter 2010; Michalak et al. 2013). Our previous studies on $P$. nigra showed, however, that temperatures of $-196{ }^{\circ} \mathrm{C}$ and $-20{ }^{\circ} \mathrm{C}$ did not cause disturbances in seed germination (Suszka et al. 2014). Since seed storage conditions impact seedling vigor, via the establishment of the root system and mycorrhizal colonization we tested the hypotheses that in contrast to short-term storage temperatures $\left(3{ }^{\circ} \mathrm{C}\right.$ and $\left.-3{ }^{\circ} \mathrm{C}\right)$, long-term storage ones $\left(-196{ }^{\circ} \mathrm{C},-20{ }^{\circ} \mathrm{C}\right.$ and $-10{ }^{\circ} \mathrm{C}$ ) will not (i) lead to a diminution in specific root length and the content of carbohydrate provided to root, and by this impact negatively the ability of seedlings to established a symbiotic relationship with mycorrhizal fungi, or (ii) influence negatively the occurrence of primary development across absorptive roots of a given order. Therefore, the objective of the current study was to determine the influence of temperature recommended for long-term $\left(-10{ }^{\circ} \mathrm{C},-20{ }^{\circ} \mathrm{C},-196^{\circ} \mathrm{C}\right)$ and short-term $\left(3{ }^{\circ} \mathrm{C},-3{ }^{\circ} \mathrm{C}\right) P$. nigra seed storage on development of root traits related to nutrient acquisition. We analyzed morphological — specific root length (SRL), and biochemical parameters (glucose, starch, total nonstructural carbohydrate and nitrogen contents) and root colonization by arbuscular and other mycorrhizal fungi. Additionally, we assessed the evidence of changes in root 
anatomy (occurrence of primary development, the proportion of cortex in root diameter) across different root orders.

\section{Materials and methods}

\subsection{Plant material}

Seeds of black poplar were collected in 2010 from three different individuals growing in floodplains near Czeszewo $\left(52^{\circ} 8^{\prime} \mathrm{N}\right.$ and $\left.17^{\circ} 30^{\prime} \mathrm{E}\right)$. Seeds were collected when catkins first began to crack open, and they were subsequently placed in an environmental chamber at $15^{\circ} \mathrm{C}$ for $72 \mathrm{~h}$ in order to further promote their opening. The seeds were then separated from the cotton-like seed hairs and prepared for storage by diminishing their water content to $7 \%$ of moisture content. Seeds were desiccated in a seed dryer at $20^{\circ} \mathrm{C}$ for about $1 \mathrm{~h}$ to $7 \%$ of moisture content. Seeds were stored in closed plastic vials at four different temperatures $\left(3{ }^{\circ} \mathrm{C},-3{ }^{\circ} \mathrm{C},-10{ }^{\circ} \mathrm{C}\right.$, $-20{ }^{\circ} \mathrm{C}$ ) or cryostored at $-196{ }^{\circ} \mathrm{C}$ in liquid nitrogen (LN) for 24 months. Chosen temperatures are recommended for shortterm $\left(3{ }^{\circ} \mathrm{C},-3{ }^{\circ} \mathrm{C}\right)$ (Tylkowski 2010; Suszka et al. 2014) or long-term $\left(-10{ }^{\circ} \mathrm{C},-20^{\circ} \mathrm{C},-196^{\circ} \mathrm{C}\right.$ ) (Sato 1955; Stanton and Villar 1996; Tylkowski 2010) storage for poplar seeds. Additionally, fresh seeds that were collected in 2012 were used as a control. Details of the storage protocols were described in Suszka et al. (2014) and Michalak et al. (2014).

\subsection{Seed germination and field growth of seedlings}

Seeds were placed directly in plastic pots filled with perlite and peat $(1: 2 \mathrm{v} / \mathrm{v})$, and a thin layer of fine sand on which seeds were sown. The plastic pots were left uncovered and supplied with ample amounts of water. After 4 months of growth, seedlings were transferred and planted in a field plot at the Zwierzyniec Experimental Forest (52 $14^{\prime} 40^{\prime} \mathrm{N}$ and $17^{\circ} 04^{\prime} 46^{\prime} \mathrm{E}$ ) where the soil is classified as sand or loam sand in the category of a eutrophic cambisol.

Three mature trees (No.1, No.2, and No.3) were the source of seeds not stored or stored at five different temperatures. The experimental design consisted of a total of 18 treatments (three tree sources $\times$ six storage conditions) spread at random within two blocks, and with a total of 10 seedlings per treatment (five per block) separated of $25 \mathrm{~cm}$. Seedlings were planted in June 9, 2012 and harvested 1 year later. When collected, root desiccation was prevented by wrapping them in a moist paper towel and transporting them to the lab in a plastic bag. Afterwards, roots were rinsed in tap water. Subsamples of the root system of each sample were scanned with an Epson Perfection V700 Photo Scanner, and subsequently analysed using WinRhizo version 2003. The scanned samples were then dried at $65{ }^{\circ} \mathrm{C}$ for 3 days and weighed. Specific root length (SRL) was determined by dividing scanned root length by dry mass $\left(\mathrm{m} \times \mathrm{g}^{-1}\right)$. For biochemical analyses and estimation of degree of fungal colonization, roots with a diameter $<2 \mathrm{~mm}$ (from seedlings developed from three tree seeds provenance), which are commonly considered as absorptive roots, were used.

\subsection{Carbohydrate analysis}

Roots were dried at $65^{\circ} \mathrm{C}$ for $72 \mathrm{~h}$, ground into powder in a Retsch MM 200 (Retsch, Haan, Germany), and later used for the chemical analyses.

The concentration of total non-structural carbohydrates (TNC — soluble carbohydrates and starch) was determined according to the method as described by Haissig and Dickson (1979) and Hansen and Møller (1975) with some modifications. The extraction of soluble carbohydrates was performed 3 times in a mixture of methanol:chloroform:water (12:5:3 by volume) (Avantor Performance Materials, Poland) and starch was determined in the precipitate remaining after extraction. Starch within the insoluble material was enzymatically converted to glucose with amyloglucosidase $(15 \mathrm{U} / \mathrm{ml})$ (Sigma, St Louis, MO, USA) after $24 \mathrm{~h}$ of incubation at $50{ }^{\circ} \mathrm{C}$. The concentration of glucose was determined by adding peroxidase-glucose oxidase-o-dianisidine dihydrochloride reagent (Sigma) and measuring absorbance at $450 \mathrm{~nm}$ within $30 \mathrm{~min}$ incubation at $25^{\circ} \mathrm{C}$. To estimate the concentration of soluble sugars, anthrone reagent (Sigma) was added to the extracted samples and placed in water bath $\left(100^{\circ} \mathrm{C}\right)$ for $12 \mathrm{~min}$. Afterwards, the reaction mixture was cooled on ice and absorbance was measured at $625 \mathrm{~nm}$ within $30 \mathrm{~min}$. The concentrations of soluble sugars and starch (using glucose as a standard) were expressed as a percentage of dry mass.

\subsection{Degree of fungal colonization}

Roots were first treated with $5 \% \mathrm{KOH}$ overnight, and after several washings in distilled water, roots were subsequently bleached in an ammonium-hydrogen peroxide solution for $10 \mathrm{~min}$. The treated roots were then stained at $80{ }^{\circ} \mathrm{C}$ for $15 \mathrm{~min}$ in $0.05 \%$ trypan blue $(w / v)$ in glycerine, lactic acid, and distilled water at a 1:1:1 ratio by volume (Brundrett et al. 1996). Afterwards, roots were washed in water that was acidified with a few drops of lactic acid and placed in a destaining solution. The presence of mycorrhizal fungi in the stained roots was assessed under a Carl Zeiss Axioskop 20 light and fluorescence microscope (Carl Zeiss, Jena, Germany). The number of fungal structures in root sections (arbuscules, vesicles, and hyphae to estimate the frequency of mycorrhizal colonization) of the same size (relative to the number of examined cells) was used to quantify the level of fungal colonization as described by Trouvelot et al. (1986) and with aid of the MYCOCALC program (http://www.dijon.inra.fr/

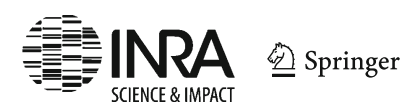


Table 1 Effect of storage temperature on morphological, biochemical, and mycorrhizal parameters of seedlings developed from seeds stored for 24 months at $3{ }^{\circ} \mathrm{C},-3{ }^{\circ} \mathrm{C},-10{ }^{\circ} \mathrm{C},-20^{\circ} \mathrm{C}$, cryopreserved at $-196{ }^{\circ} \mathrm{C}$, or freshly harvested (not stored). General mixed model with "tree" as a random factor

\begin{tabular}{|c|c|c|c|c|}
\hline & Studied traits (unit definition) & $\mathrm{DF}$ & $\mathrm{F}$ & $P$ \\
\hline \multirow{2}{*}{$\begin{array}{l}\text { Root morphology } \\
\text { trait }\end{array}$} & $\operatorname{SRL}^{\mathrm{a}}\left(\mathrm{m} \times \mathrm{g}^{-1}\right)$ & 5 & 0.21 & 0.956 \\
\hline & SRL without TNC $\left(\mathrm{m} \times \mathrm{g}^{-1}\right)$ & 5 & 0.35 & 0.880 \\
\hline \multirow{3}{*}{$\begin{array}{l}\text { Root chemistry } \\
\text { traits }\end{array}$} & Glucose content $\left(\%\right.$ d.m. $\left.{ }^{\mathrm{b}}\right)$ & 5 & 1.52 & 0.215 \\
\hline & Starch content ( $\%$ d.m.) & 5 & 0.58 & 0.712 \\
\hline & $\begin{array}{l}\text { Total nonstructural carbohydrates } \\
\text { (TNC, \% d.m.) }\end{array}$ & 5 & 0.87 & 0.509 \\
\hline \multirow[t]{5}{*}{ Mycorrhiza traits ${ }^{\mathrm{c}}$} & $\mathrm{F}(\%)$ & 5 & 0.99 & 0.435 \\
\hline & $\mathrm{M}(\%)$ & 5 & 1.92 & 0.096 \\
\hline & $\mathrm{m}(\%)$ & 5 & 2.14 & 0.065 \\
\hline & $\mathrm{a}(\%)$ & 5 & 0.50 & 0.776 \\
\hline & $\mathrm{A}(\%)$ & 5 & 0.51 & 0.766 \\
\hline
\end{tabular}

${ }^{\text {a }} S R L$ root specific length, $T N C$ total non-structural carbohydrates

${ }^{\mathrm{b}}$ d.m. dry mass

${ }^{\mathrm{c}} F$ frequency of mycorrhiza in the root system, $M$ intensity of the mycorrhizal colonization in the root system, $m$ intensity of the mycorrhizal colonization in the root fragments, $a$ arbuscule abundance in mycorrhizal parts of the root fragments, $A$ arbuscule abundance in the root system

mychintec/Mycocalc-prg/download.html) and expressed as a percentage.

\subsection{Root order anatomy and nitrogen content}

The storage temperature did not affect seed germination nor morphological traits or fungal colonization of seedlings developed from seeds obtained from the parent tree No. 1 (Table 1, Table S1). To check if this lack of effect was also reflected across root order, more detailed anatomical studies were performed. Roots from five seedlings per storage temperature were divided into individual orders as described by Pregitzer et al. (2002). Only living roots were assessed in this study and were classified based on texture and visual appearance. After harvesting by orders, root were immediately placed in $4 \%$ PFA (paraformaldehyde; Polysciences, Warrington, PA, USA) and $4 \%$ in $0.1 \mathrm{M}$ sodium cacodylate buffer. After
$24 \mathrm{~h}$, roots were washed in $0.05 \mathrm{M}$ sodium cacodylate buffer, dehydrated in an alcohol series and embedded in Technovit 7100 resin (Heraeus Kulzer, Wehrheim, Germany). Crosssections $(5 \mu \mathrm{M})$ obtained with a microtome (Leica RM 2265, Wetzlar, Germany) were stained in $0.05 \%$ toluidine blue O (Sigma, St Louis, MO, USA) in $1 \%$ sodium tetraborate buffer and then examined using a Carl Zeiss Axioscope 20 light and fluorescence microscope (Carl Zeiss, Jena, Germany). The total number of roots analyzed in anatomical studies from 1 st to 4 th order was 428. In anatomical cross-sections, the following traits were determined: diameter of the root, the width of cortex and stele (to calculate the proportion of cortical tissue in whole root diameter). The primary development was estimated based on the presence of vascular cambium and periderm occurrence, where phellem is the outside layer of periderm (Hejnowicz 2002).

Root orders were dried at $65{ }^{\circ} \mathrm{C}$ for $72 \mathrm{~h}$, ground into powder in a Retsch MM 200 (Retsch, Haan, Germany), and later used to determine $\mathrm{N}$ and $\mathrm{C}$ contents. Nitrogen and carbon contents were determined using an Elemental Combustion System CHNS-O 4010 analyzer (Costech Instruments, Italy/ USA) and expressed as a percentage of dry mass.

\subsection{Statistical analysis}

All percentage data were arc sin transformed prior to analysis according to the Bliss equation. In figures, non-transformed data are presented. A generalized linear mixed model (GLMM) with "tree" as a random factor was applied to examine the effect of storage temperature on morphological root traits and fungal colonization of roots. To estimate this effect, ten seedlings per each treatment grown from seeds originating from three mature trees (No. 1, No.2, No.3) were considered. Since storage temperature affected neither morphological traits nor colonization by fungi, the effect of storage temperature and root order was determined using a two-way analysis of variance only on seedlings originating from seeds of tree No. 1, where there were no observed differences in seed germination capacity after storage (five seedlings for each treatment). To estimate in detail how temperature treatment influenced anatomical traits within particular root order, one way

Table 2 Two-way ANOVA of the effect of seed treatment $\left(3{ }^{\circ} \mathrm{C},-3{ }^{\circ} \mathrm{C},-10{ }^{\circ} \mathrm{C},-20^{\circ} \mathrm{C}\right.$ and cryopreserved at $-196{ }^{\circ} \mathrm{C}$ for 24 months and freshly harvested) and root order on anatomical traits of seedling root. Seeds to experimental design came from tree No. 1

\begin{tabular}{|c|c|c|c|c|c|c|c|c|}
\hline & \multicolumn{2}{|c|}{$\%$ of roots with primary development } & \multicolumn{2}{|c|}{ Root diameter $(\mu \mathrm{m})$} & \multicolumn{2}{|c|}{$\%$ cortex in root diameter } & \multicolumn{2}{|c|}{ Nitrogen content $\left(\%\right.$ of $\left.d . \mathrm{m}^{\mathrm{a}}{ }^{\mathrm{a}}\right)$} \\
\hline & $\mathrm{F}$ & $P$ & $\mathrm{~F}$ & $P$ & $\mathrm{~F}$ & $P$ & $\mathrm{~F}$ & $P$ \\
\hline Treatment & 9.08 & $<0.001$ & 2.60 & 0.025 & 18.12 & $<0.001$ & 6.39 & $<0.001$ \\
\hline Root order & 102.26 & $<0.001$ & 120.51 & $<0.001$ & 156.64 & $<0.001$ & 59.85 & $<0.001$ \\
\hline Treatment $\times$ root order & 2.38 & 0.021 & 2.26 & 0.005 & 4.91 & $<0.001$ & 0.58 & 0.860 \\
\hline
\end{tabular}

a d.m. dry mass 
ANOVA was applied. The Tukey test was used to examine the differences between the means $(P=0.05)$. To indicate relationship between studied variables, Pearson's coefficient was used. All analyses were conducted using the statistical analysis software, Statistica version 8.0 (StatSoft Tulsa, OK, USA).

\section{Results}

As was confirmed by the GLMM with tree as a random factor, structural and biochemical analyses of fine roots (diameter $<$ $2 \mathrm{~mm}$ ) did not reveal any significant differences between seeds stored at different temperatures (Table 1). For instance, storage conditions did not affect AMF colonization (Table 1). However, the relative frequency of arbuscules negatively correlated with the concentration of total nonstructural carbohydrates $(r=-0.64, P=0.024)$ (Table S2).

When root anatomy was studied, seed storage temperature turned out to have a significant impact on the proportion of roots with primary development (Tables 2 and 3). Seed storage at lower temperatures $\left(-196{ }^{\circ} \mathrm{C}\right.$ and $\left.-20{ }^{\circ} \mathrm{C}\right)$ resulted in the development of seedlings with a higher mean percentage of roots with primary development than the proportion observed in seedlings from seeds stored at other temperatures (Fig. 1). The proportion of roots with primary development (derived from seeds stored at $-196^{\circ} \mathrm{C}$ and $-20^{\circ} \mathrm{C}$ ) were equal to these observed in fresh seeds (i.e., seeds not stored). Variation was also observed across root orders, and an interaction between root orders and temperature treatment was also significant (Table 2). Briefly, first-order roots exhibited only primary development, regardless of the storage conditions (Table 3). However, significant differences in the studied traits

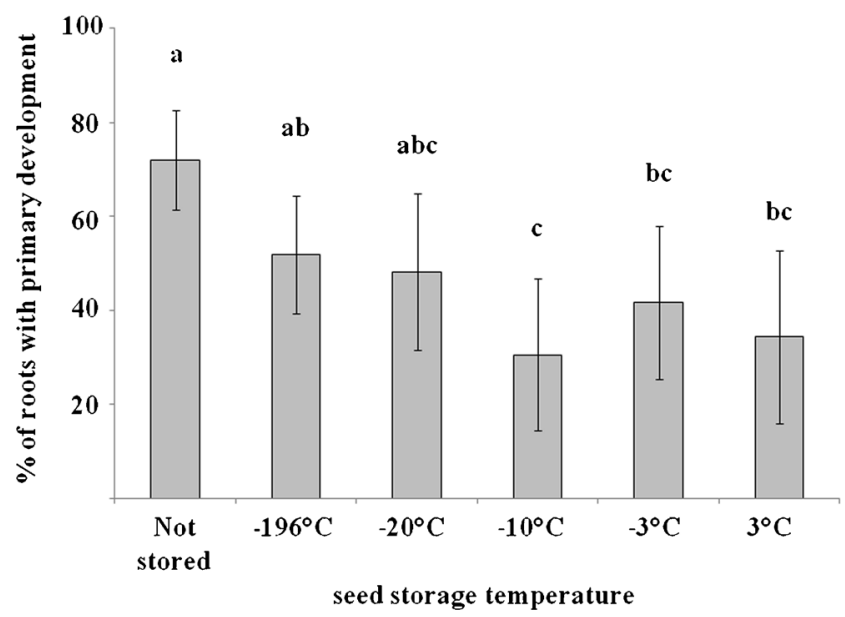

Fig. 1 Percentage of roots with primary development of seedlings derived from seeds (obtained from tree No. 1) stored for 24 months at $3{ }^{\circ} \mathrm{C},-3{ }^{\circ} \mathrm{C},-10{ }^{\circ} \mathrm{C},-20{ }^{\circ} \mathrm{C}$, cryopreserved at $-196{ }^{\circ} \mathrm{C}$, or freshly harvested (not stored). Values with the same letter are not significantly different at $P<0.05$ (Tukey test). Bars represent mean values across four orders of roots, whiskers represent SE of the mean 
were detected in third-order roots but only approached being significant in second-order roots (Table 3). Within fourth order, apart from roots that developed from freshly harvested seeds, roots of seedlings grown from stored seeds did not display primary development (Table 3 ).

Overall, root diameter across root order and seed temperature treatment varied significantly, and a significant interaction between root order and storage temperature was also observed (Table 2). The largest diameter of roots was observed in seedlings that developed from seeds stored at $-196^{\circ} \mathrm{C}$ and $-20^{\circ} \mathrm{C}$ (408 $\mu \mathrm{m} \pm 12.6$ and $390.7 \mu \mathrm{m} \pm 15.6$, mean \pm SE,respectively) and the more narrow diameter $(376.82 \mu \mathrm{m} \pm 15.38)$ was observed in roots of seedlings that developed from seeds stored at $-3{ }^{\circ} \mathrm{C}$ (Fig. 2 and Table 3). The diameter of roots in seedlings derived from fresh seeds was intermediate $(395.3 \mu \mathrm{m} \pm$ 11.9) (Fig. 2).

The proportion of cortical tissue to the diameter of whole roots differed significantly among root order and also among storage conditions (Table 2). The highest proportion was observed in seedlings that were derived from fresh seeds, and the lowest was in those developed from seeds stored at $-10{ }^{\circ} \mathrm{C}$ and at $3{ }^{\circ} \mathrm{C}$ (Fig. 3).

Nitrogen content decreased significantly across root orders, we also observed a significant effect of storage conditions (Table 2). When data from all four orders of roots were pooled together, the patterns reflected the differences in clustered storage temperatures with the lowest levels of nitrogen content were observed in seedlings derived from seeds stored at $-20^{\circ} \mathrm{C}$ and $-10^{\circ} \mathrm{C}$, and the highest $\mathrm{N}$ levels were in seedlings derived from seeds stored at $3{ }^{\circ} \mathrm{C}$ and $-196{ }^{\circ} \mathrm{C}$ (Fig. 4).

The correlation coefficient of average values indicated that the percentage of nitrogen content was positively correlated with the percentage of roots with primary development $(r=$

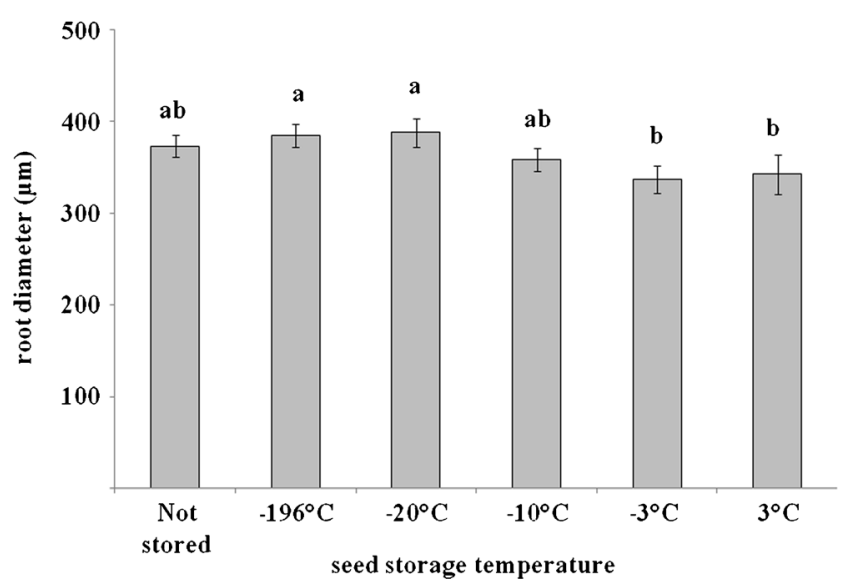

Fig. 2 Root diameter of seedlings derived from seeds (obtained from tree No. 1) stored for 24 months at $3{ }^{\circ} \mathrm{C},-3{ }^{\circ} \mathrm{C},-10{ }^{\circ} \mathrm{C},-20{ }^{\circ} \mathrm{C}$, cryopreserved at $-196{ }^{\circ} \mathrm{C}$, or freshly harvested (not stored). Values with the same lower case letter are not significantly different at $P<0.05$ (Tukey test). Bars represent mean values across four orders of roots, whiskers represent SE of the mean

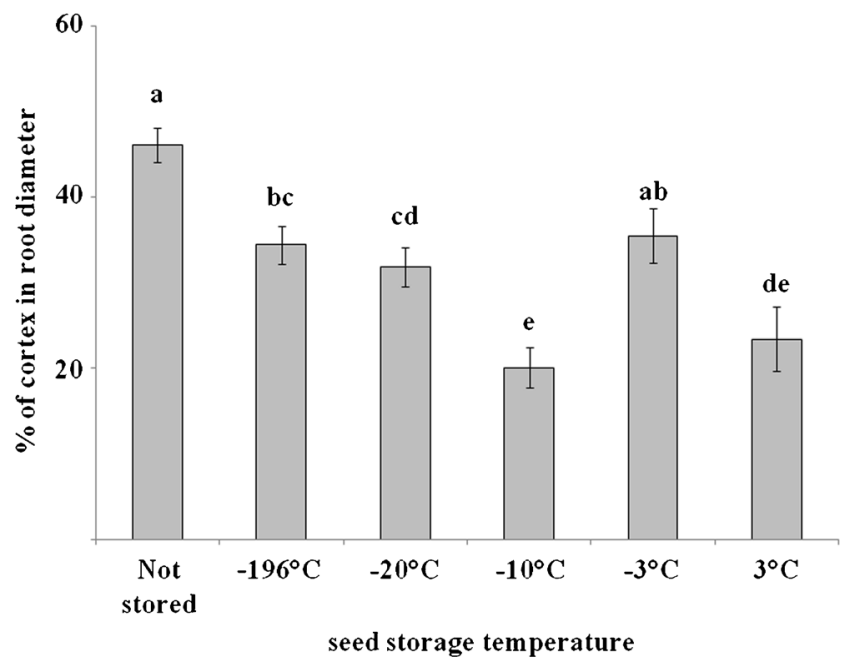

Fig. 3 Proportion of cortex in the root diameter represented in the root diamter of seedlings derived from seeds (obtained from tree No. 1) stored for 24 months at $3{ }^{\circ} \mathrm{C},-3{ }^{\circ} \mathrm{C},-10^{\circ} \mathrm{C},-20^{\circ} \mathrm{C}$, cryopreserved at $-196^{\circ} \mathrm{C}$, or freshly harvested (not stored). Values with the same lower case letter are not significantly different at $P<0.05$ (Tukey test). Bars represent mean values across four orders of roots, whiskers represent SE of the mean

0.82, $P<0.001)$, and with the proportion of cortical tissue in root diameter $(r=0.79, P<0.001)$ (Table 4$)$.

\section{Discussion}

Seed storage for 2 years at -196 and $-20^{\circ} \mathrm{C}$ as well as at the other temperatures tested $\left(3,-3\right.$ and $\left.-10{ }^{\circ} \mathrm{C}\right)$ did not influence morphological and biochemical traits of fine roots as well as colonization by mycorrhizal fungi with seedlings from freshly harvest seeds. However, the effect of seed storage temperature

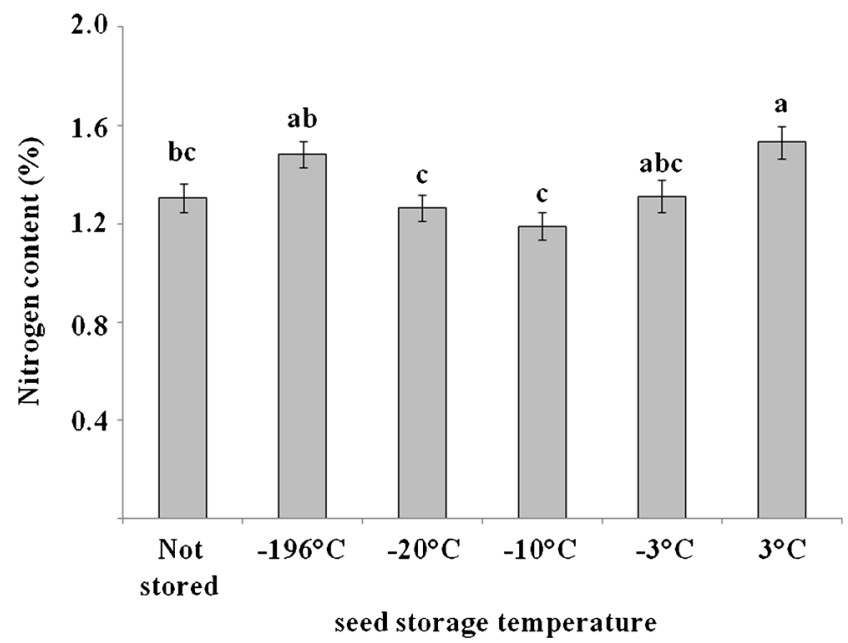

Fig. 4 Nitrogen content in roots of seedlings derived from seeds (obtained from tree No. 1) stored for 24 months at $3{ }^{\circ} \mathrm{C},-3{ }^{\circ} \mathrm{C},-10{ }^{\circ} \mathrm{C}$, $-20{ }^{\circ} \mathrm{C}$, cryopreserved at $-196{ }^{\circ} \mathrm{C}$, or freshly harvested (not stored). Values with the same lower case letter are not significantly different at $P<0.05$ (Tukey test). Bars represent mean values across four orders of roots, whiskers represent SE of the mean 
Table 4 Pearson correlation coefficient $(r)$ for anatomical traits and nitrogen content in four root order of $P$. nigra seedlings derived from freshly harvested, not stored seeds and those stored at $3{ }^{\circ} \mathrm{C},-3{ }^{\circ} \mathrm{C}$, $-10{ }^{\circ} \mathrm{C},-20{ }^{\circ} \mathrm{C}$ and cryopreserved at $-196{ }^{\circ} \mathrm{C}$ for 24 months obtained from individual black poplar tree (No. 1)

\begin{tabular}{|c|c|c|c|}
\hline & $\begin{array}{l}\% \text { of roots with } \\
\text { primary } \\
\text { development }\end{array}$ & $\begin{array}{l}\text { Root } \\
\text { diameter } \\
(\mu \mathrm{m})\end{array}$ & $\begin{array}{l}\% \text { cortex in } \\
\text { root } \\
\text { diameter }\end{array}$ \\
\hline Root diameter $(\mu \mathrm{m})$ & $0.95 * * *$ & & \\
\hline $\begin{array}{l}\% \text { cortex in } \\
\text { root diameter }\end{array}$ & $-0.51^{*}$ & $-0.54 * *$ & \\
\hline $\begin{array}{l}\text { Nitrogen content } \\
\left(\% \text { of d.m. }{ }^{a}\right)\end{array}$ & $0.82 * * *$ & $-0.55^{* *}$ & $0.79 * *$ \\
\hline
\end{tabular}

${ }^{a} d . m$. dry mass

Values are significant at: $* * P<0.01, * * * P<0.001$

particularly of $3{ }^{\circ} \mathrm{C},-3{ }^{\circ} \mathrm{C}$, and $10^{\circ} \mathrm{C}$ compared with the other treatments on anatomical traits (primary vs secondary development, proportion of cortical tissue to diameter) that are essential for supplying adequate nutrients for growth was noticeable.

While initial seed viability is an essential aspect of defining optimum conditions for long-term storage (Walters et al. 2004; Popova et al. 2012), the importance of seed viability on the development of seedling root systems is less understood. In the present study of seedlings grown in field condition, analysis of roots with a diameter $<2 \mathrm{~mm}$, which is commonly considered to have absorptive function (Finér et al. 2007), did not show any significant differences in root system morphology (SRL) after seed storage at different temperatures. Our previous studies indicated that black poplar seeds can be cryostored at an appropriate water content, regardless of the seed origin or quality, without impacting seed viability (Michalak et al. 2014). Moreover, after 24 months of storage of $P$. nigra seeds in LN at the optimal level of moisture content, the germination levels of cryostored seeds were similar to freshly harvested seeds (Suszka et al. 2014). Our current results indicated, however, that seedlings produced from seeds stored at $-20{ }^{\circ} \mathrm{C}$ or $-196{ }^{\circ} \mathrm{C}$ (i.e., cryopreserved seeds) showed a similar percentage of roots with primary development to that of the seedlings from freshly harvested seeds. Seedlings derived from seeds stored at other temperatures have a lower percentage of roots with primary development when compared to the seedlings from freshly harvested seeds. Although the proportion of roots with primary development was provided by significance in the 3 root order, and marginally in the 2nd, architecture of the root system can affect similar to natural (without storage) growth of seedling derived from seed stored in lower temperatures. A high percentage of primary development has been described to increase surface area for effective root resource acquisition (McCormack et al. 2014) and the physiological response that is essential for adapting to adverse environmental changes (Smithwick et al.
2013). Due to their higher sensitivity to the environment, a high proportion of roots with primary development may result in changes in plant growth that can alleviate the adverse impact of unfavorable environmental conditions (Guo et al. 2004).

The presence of primary cortex associated with the primary development may also reflect the ability of the root system in relation to resource acquisition and adaptation to different soil conditions. This is of special importance, because our present study indicated that the higher storage temperatures (except for $-3{ }^{\circ} \mathrm{C}$ ) had rather a negative impact on cortical tissue proportion, a parameter which is most sensitive to environmental changes ( $\mathrm{Gu}$ et al. 2014). Moreover, $\mathrm{N}$ concentration was positively correlated with the percentage of roots with primary development and cortical tissue. $\mathrm{N}$ content is associated with protein content, respiration, and metabolic activity (Lambers et al. 2005). Stadelmann et al. (1998) reported that low $\mathrm{N}$ concentration and the high $\mathrm{C} / \mathrm{N}$ ratio could be attributed to the high mortality and poor development of root system in Festuca rubra seedlings obtained from in-vitro culture. Presence of vital cortical tissue is necessary for successful mycorrhizal colonization (Peterson et al. 1999; Brundrett 2002), as colonization of root tissues by arbuscular mycorrhiza is related to the amount of primary cortex, and differences in root anatomy may impact absorptive ability (Guo et al. 2008). However, our study did not show such an obvious dependence, as no differences in the number of arbusculae were observed in relation to seed storage temperature. The plants in our study, however, were grown under optimal conditions, which could explain this lack of dependency, and additionally the correlation found in our study of cortical tissue with nitrogen content may have influenced mycorrhizal colonization. Plant reduce $\mathrm{C}$ allocation to $\mathrm{AM}$ fungi, since it constitutes a significant cost to the host plant (Olsson et al. 2005), and high nitrogen content may also reduce $\mathrm{C}$ supply to $\mathrm{AM}$ fungi (Olsson et al. 2005; Johnson et al. 2010); we also found that arbuscule abundance was negatively correlated with total nonstructural carbohydrates in roots. However, under stress conditions that occur with great regularity in the course of growth, the current lack of differences in mycorrhizal colonization can bring unexpected results in the form of weakening growth or descending the tree. A different pattern of colonization towards the currently observed can occur in deteriorated environmental conditions, as Treseder and Allen (2002) indicated that limitation of $\mathrm{N}$ enhances AM colonization.

We observed, however, that cryopreservation and storage in $-20{ }^{\circ} \mathrm{C}$ are methods that better retain the characteristics of roots compared with the plants that are not stored (percentage of root with primary development), making them suitable for proper preservation of root system growth pattern of future Populus seedlings. In agreement with the present findings of our studies, Vendrame et al. (2007) did not observe any abnormalities, disease, or nutritional deficiencies in seedlings of 
Dendrobium that were developed from cryopreserved seeds. Sershen and Pammeneter (2010), however, reported that Amaryllis belladonna $\mathrm{L}$. seedlings derived from cryopreserved, recalcitrant zygotic embryos were less vigorous and more prone to hydraulic failure than non-preserved seedlings.

\section{Conclusions}

Our study demonstrated that the storage of seeds, with appropriate water content, at different temperatures in the range of 3 to $-196{ }^{\circ} \mathrm{C}$ did not have an effect on the morphology or biochemistry of seedling root systems, nor on the level of mycorrhizal colonization. Storage temperature did, however, affect root anatomy (proportion of roots with primary development and proportion of cortex in root diameter), which in turn may alter the ability of the root system to acquire nutrients under adverse environmental conditions. Therefore, detailed studies, not limited to germination assays (evaluate only the potential success of seedling development) but extended to field studies, are needed to develop optimal protocols for seed storage. Data from the present study indicate that seed storage at $-20{ }^{\circ} \mathrm{C}$ or $-196{ }^{\circ} \mathrm{C}$ will ensure the development of seedling root systems with anatomical traits similar to those of seedlings derived from freshly harvested, not stored seeds.

Acknowledgments We would like to thank dr Roma Zytkowiak for the biochemical analysis of carbohydrate content in roots. Discussions and valuable comments from anonymous reviewers greatly improved this manuscript.

Funding This research has been financially supported by the National Science Centre, Poland (project no N N309 429 138).

Open Access This article is distributed under the terms of the Creative Commons Attribution License which permits any use, distribution, and reproduction in any medium, provided the original author(s) and the source are credited.

\section{References}

Braatne JH, Rood SB, Heilman PE (1996) Life-history, ecology, and conservation of riparian cottonwoods in North America. In: Stettler RF, Bradshaw HD, Heilman PE, Hinckley TM (eds) Biology of Populus and its implications for management and conservation. NRC Research, Ottawa, pp 57-86

Brundrett MC (2002) Coevolution of roots and mycorrhizas of land plants. New Phytol 154:275-304. doi:10.1046/j.1469-8137.2002. 00397.x

Brundrett MC, Bougher N, Dell B, Grove T, Malajczuk N (1996) Working with mycorrhizas in forestry and agriculture. Aust Cent Int Agric Res Monogr Ser Number 32

Caswell KL, Kartha KK (2009) Recovery of plants from pea and strawberry meristems cryopreserved for 28 years. CryoLetters $30: 41-46$
Corenblit D, Steiger J, González E, Gurnell AM, Charrier G, Darrozes J, Dousseau J, Julien F, Lambs L, Larrue S, Roussel E, Vautier F, Voldoire O (2014) The biogeomorphological life cycle of poplars during the fluvial biogeomorphological succession: a special focus on Populus nigra L. Earth Surf Process Landf 39:546-563. doi:10. 1002/esp.3515

Fernández-Martínez M, Vicca S, Janssens IA, Sardans J, Luyssaert S, Campioli M, Chapin FS III, Ciais P, Malhi Y, Obersteiner M, Papale D, Piao SL, Reichstein M, Rodà F, Peñuelas J (2014) Nutrient availability as the key regulator of global forest carbon balance. Nat Clim Chang 4:471-476. doi:10.1038/nclimate2177

Finér L, Helmisaari HS, Lohmus K, Majdi H, Brunner I, Borja I, Eldhuset T, Godbold D, Grebenc T, Konopka B et al (2007) Variation in fine root biomass of three European tree species: Beech (Fagus sylvatica L.), Norway spruce (Picea abies L. Karst.), and Scots pine (Pinus sylvestris L.). Plant Biosyst 141:394-405. doi:10.1080/ 11263500701625897

Gryta H, Carriconde F, Charcosset JY, Jargeat P, Gardes M (2006) Population dynamics of the ectomycorrhizal fungal species Tricholoma populinum and Tricholoma scalpturatum associated with black poplar under differing environmental conditions. Environ Microbiol 8:773-786. doi:10.1111/j.1462-2920.2005. 00957.X

Gu J, Xu Y, Dong X, Wang H, Wang Z (2014) Root diameter variations explained by anatomy and phylogeny of 50 tropical and temperate tree species. Tree Physiol. doi:10.1093/treephys/tpu019

Guo DL, Mitchell RJ, Hendricks JJ (2004) Fine root branch orders respond differentially to carbon source-sink manipulations in a longleaf pine forest. Oecologia 140:450-457. doi:10.1007/s00442004-1596-1

Guo DL, Mitchell RJ, Withington JM, Fan P-P, Hendricks JJ (2008) Endogenous and exogenous controls of root life span, mortality and nitrogen flux in a longleaf pine forest: root branch order predominates. J Ecol 6:737-745. doi:10.1111/j.1365-2745.2008. 01385.x

Haissig BE, Dickson RE (1979) Starch measurement in plant tissue using enzymatic hydrolysis. Physiol Plant 47:151-157. doi:10.1111/j. 1399-3054.1979.tb03207.x

Hansen J, Møller I (1975) Percolation of starch and soluble carbohydrates from plant tissue for quantitative determination with anthrone. Anal Biochem 68:87-94. doi:10.1016/0003-2697(75)90682-X

Harner MJ, Mummey DL, Stanford JA, Rillig MC (2010) Arbuscular mycorrhizal fungi enhance spotted knapweed growth across riparian chronosequence. Biol Invasions 12:1481-1490. doi:10.1007/ s10530-009-9559-4

Hejnowicz Z (2002) Anatomia i histogeneza roślin drzewiastych [Anatomy and histogenesis of woody plants]. PWN, Warszawa

Hodge A, Berta G, Doussan C, Merchan F, Crespi M (2009) Plant root growth, architecture and function. Plant Soil 321:153-187. doi:10. 1007/s11104-009-9929-9

Hughes FM, Rood SB (2003) Allocation of river flows for restoration of floodplain forest ecosystems: a review of approaches and their applicability in Europe. Environ Manag 32:12-33. doi:10.1007/ s00267-003-2834-8

Johnson NC, Wilson GW, Bowker MA, Wilson JA, Miller RM (2010) Resource limitation is a driver of local adaptation in mycorrhizal symbioses. PNAS 107:2093-2098. doi:10.1073/ pnas.0906710107

Karrenberg S, Blaser S, Kollmann J, Speck T, Edwards PJ (2003) Root anchorage of saplings and cuttings of woody pioneer species in a riparian environment. Funct Ecol 17:170-177. doi:10.1046/j.13652435.2003.00709.x

Lambers H, Robinson SA, Ribas-Carbo M (2005) Regulation of respiration in vivo. In: Lambers H, Ribas-Carbo M (eds.) Plant respiration. Springer, Dordrecht, pp 1-15 
Lefèvre F, Légionnet A, de Vries S, Turok J (1998) Strategies for the conservation of a pioneer tree species, Populus nigra L. in Europe. Genet Sel Evol 30:181-196. doi:10.1051/gse:19980711

Leigh J, Hodge A, Fitter AH (2009) Arbuscular mycorrhizal fungi can transfer substantial amounts of nitrogen to their host plant from organic material. New Phytol 181:199-207. doi:10.1111/j.14698137.2008.02630.x

Linington SH, Pritchard HW (2001) Gene banks. In: Levin SA (ed) Encyclopedia of biodiversity, vol 3. Academic Press, New York, pp 165-181

Lytle DA (2001) Disturbance regimes and life-history evolution. Am Nat 157:525-536. doi:10.1086/319930

Malik AR, Shamet GS, Butola JS, Bhat GM, Mir AA, Nabi G (2013) Standardization of seed storage conditions in chilgoza pine (Pinus gerardiana Wall.): an endangered pine of Hind Kush Himalaya. Trees 27:1497-1501. doi:10.1007/s00468-013-0868-y

Martinez-Montero ME, Mora N, Quinones J, Gonzalez-Arnao MT, Engelmann F, Lorenzo JC (2002) Effect of cryopreservation on the structural and functional integrity of cell membranes of sugarcane (Saccharum sp.) embryogenic calluses. CryoLetters 23:237-244

McCormack ML, Lavely E, Ma Z (2014) Fine-root and mycorrhizal traits help explain ecosystem processes and responses to global change. New Phytol 204:455-458. doi:10.1111/nph.13023

Michalak M, Barciszewska MZ, Barciszewski J, Plitta BP, Chmielarz P (2013) Global changes in DNA methylation in seeds and seedlings of Pyrus communis after seed desiccation and storage. PLoS One 8: e70693. doi:10.1371/journal.pone.007069

Michalak M, Plitta BP, Tylkowski T, Chmielarz P, Suszka J (2014) Desiccation tolerance and cryopreservation of seeds of black poplar (Populus nigra L.), an disappearing tree species in Europe. Eur J For Res. doi:10.1007/s10342-014-0832-4

Olsson PA, Burleigh SH, Van Aarle IM (2005) The influence of external nitrogen on carbon allocation to Glomus intraradices in monoxenic arbuscular mycorrhiza. New Phytol 168:677-686. doi:10.1111/j. 1469-8137.2005.01532.x

Peterson CA, Enstone DE, Taylor JH (1999) Pine root structure and its potential significance for root function. Plant Soil 217:205-213. doi: 10.1023/A: 1004668522795

Popova EV, Hyun KD, Hee HS, Pritchard HW, Cheon LJ (2012) Narrowing of the critical hydration window for cryopreservation of Salix caprea seeds following ageing and a reduction vigour. CryoLetters 33:219-230

Popova EV, Kim DH, Han SH, Moltchanova E, Pritchard HW, Hong YP (2013) Systematic overestimation of Salicaceae seed survival using radicle emergence in response to drying and storage: implications for ex situ seed banking. Acta Physiol Plant 35:3015-3025. doi:10. 1007/s11738-013-1334-6

Pregitzer KS (2002) The fine roots of trees - a new perspective. New Phytol 156:267-270. doi:10.1046/j.1469-8137.2002.00413 1.x

Pregitzer KS, DeForest JL, Burton AJ, Allen MF, Ruess RW, Hendrick RL (2002) Fine root architecture of nine North American trees. Ecol Monogr 72:293-309. doi:10.1890/0012-9615(2002) 072[0293:FRAONN]2.0.CO;2

Rooney DC, Prosser JI, Bending GD, Baggs EM, Killham K, Hodge A (2011) Effect of arbuscular mycorrhizal colonisation on the growth and phosphorus nutrition of Populus euramericana cv Ghoy. Biomass Bioenergy 35:4605-4612. doi:10.1016/j.biombioe.2011.08.015
Sato Y (1955) On the viability of Salicaceae seeds. Res Bull Exp For Hokkaido Univ 14:225-266.

Seiwa K, Tozawa M, Ueno N, Kimura M, Yamasaki M, Maruyama K (2008) Roles of cottony hairs in directed seed dispersal in riparian willows. Plant Ecol 198:27-35. doi:10.1007/s11258-007-9382-x

Sershen BP, Pammeneter NW (2010) Effects of cryopreservation of recalcitrant Amaryllis belladonna zygotic embryos on vigor of recovered seedlings: a case of stress 'hangover'? Physiol Plant 139:205219. doi:10.1111/j.1399-3054.2010.01358.x

Smithwick EA, Eissenstat DM, Lovett GM, Bowden RD, Rustad LE, Driscoll CT (2013) Root stress and nitrogen deposition: consequences and research priorities. New Phytol 197:712-719. doi:10. 1111/nph.12081

Stadelmann FJ, Boller B, Spangenberg G, Kölliker R, Messerli M, Wang ZY, Nösberger J (1998) Fertility and growth in the field of Lolium perenne and Festuca rubra plants regenerated from suspension cultured cells and protoplasts. Plant Breed 117:37-43. doi:10.1111/j. 1439-0523.1998.tb01445.x

Stanton BJ, Villar M (1996) Controlled reproduction of Populus. In: Part I, Serttler RF, Bradshaw HD Jr, Heilman PE, Hinckley TM (eds) Biology of Populus and its implications for management and conservation. NCR Research Press, National Research Council of Canada, Ottawa, pp 113-138

Storme V, Vanden Broeck A, Ivens B, Halfmaerten D, Van Slycken J, Castiglione S, Grassi F, Fossati T, Cottrell JE, Tabbener HE, Lefévre F, Saintagne C, Fluch S, Krystufek V, Burg K, Bordács S, Borovics A, Gebhardt K, Vornam B, Pohl A, Alba N, Agfflndez D, Maestro C, Notivol E, Bovenschen J, van Dam BC, van der Schoot J, Vosman B, Boerjan W, Smulders MJM (2004) Ex-situ conservation of Black poplar in Europe: genetic diversity in nine gene bank collections and their value for nature development. Theor Appl Genet 108:969-981. doi:10.1007/s00122-003-1523-6

Suszka J, Plitta BP, Michalak M, Bujarska-Borkowska B, Tylkowski T, Chmielarz P (2014) Optimal seed water content and storage temperature for preservation of Populus nigra L. germplasm. Ann For Sci 71:543-549. doi:10.1007/s13595-014-0368-2

Treseder KK, Allen MF (2002) Direct nitrogen and phosphorus limitation of arbuscular mycorrhizal fungi: a model and field test. New Phytol 155:507-515. doi:10.1046/j.1469-8137.2002.00470.x

Trouvelot A, Kough JL, Gianinazzi-Pearson V (1986) Mesure du taux de mycorhization VA d'un système radiculaire. Recherche de méthodes d'estimation ayant une signification fonctionnelle. INRA, Paris

Tylkowski T (2010) Przekształcenia w składzie dendroflory w dolinie środkowej Warty [Transformation of dendroflora composition in the middle valley of the Warta River]. Acta Sci Pol Ad Locorum 9:117-124

Vendrame WA, Carvalho VS, Dias JMM (2007) In vitro germination and seedling development of cryopreserved Dendrobium hybrid mature seeds. Sci Hortic 114:188-193. doi:10.1016/j.scienta.2007.06.006

Villar M, Forestier O (2006) Ressources génétiques du peuplier noir (Populus nigra L.) dans la plaine rhénane alsacienne: états des lieux, programme de conservation et perspectives. WSG BadenWurttemberg 10:85-93

Walters C, Wheeler L, Stanwood PC (2004) Longevity of cryogenically stored seeds. Cryobiology 48:229-244. doi:10.1016/j.cryobiol. 2004.01.007 